\title{
Think Pair Share sebagai Model Pembelajaran Kooperatif untuk Peningkatan Kemampuan Pemecahan Masalah Matematis
}

\author{
Syintia Siti Latifah ${ }^{1 *}$, Irena Puji Luritawaty ${ }^{2}$ \\ Program Studi Pendidikan Matematika, Institut Pendidikan Indonesia \\ Jalan Terusan Pahlawan, Garut, Jawa Barat, Indonesia \\ 1*sintiasitilatifah@gmail.com, ${ }^{2}$ irenapuji@yahoo.com
}

Artikel diterima: 30-11-2019, direvisi: 29-01-2020, diterbitkan: 31-01-2020

\begin{abstract}
Abstrak
Diperlukan upaya untuk meningkatkan pencapaian kemampuan pemecahan masalah matematis yang masih rendah, misalnya menggunakan model pembelajaran tipe Think Pair Share. Tujuan penelitian yaitu mengetahui peningkatan dan seberapa jauh kemampuan pemecahan masalah matematis siswa dapat meningkat dengan model pembelajaran Think Pair Share. Metode penelitian yaitu kuasi eksperimen, dengan populasi siswa kelas VIII di satu SMP di Kabupaten Garut. Sampel yaitu kelas VIII-A sejumlah 33 siswa, dipilih berdasarkan teknik purposive sampling. Instrumen berupa soal tes uraian kemampuan pemecahan masalah diujikan sebelum dan sesudah pembelajaran. Hasil analisis data pada kelas Think Pair Share menunjukkan peningkatan kemampuan pemecahan masalah matematis berkategori sedang. Pembelajaran kooperatif tipe Think Pair Share terbukti cukup efektif meningkatkan kemampuan pemecahan masalah matematis siswa.

Kata Kunci: Kemampuan pemecahan masalah matematis, Think Pair Share, kuasi eksperimen.

Think Pair Share Type Cooperative Learning Model to improve Mathematical Problem Solving Ability

Abstract

Efforts are needed to improve the achievement of mathematical problem-solving abilities that are still low, for example using the Think Pair Share type of learning model. The purpose of this research is to find out how much improvement and how much the students' mathematical problem-solving ability increases through the Think Pair Share learning model. The research method is quasi-experimental, with a population of eighth grade students in one junior high school in Garut Regency. The sample is class VIII-A with 33 students, selected based on purposive sampling technique. Instruments in the form of test questions describing problemsolving abilities were tested before and after learning. The results of data analysis in the Think Pair Share class showed an increase in the ability to solve mathematical problems in the medium category. Cooperative learning Think Pair Share type proved effective enough to improve students' mathematical problem-solving abilities.

Keywords: Mathematical problem solving ability, Think Pair Share, quasi-experimental.
\end{abstract}




\section{Pendahuluan}

Dasar ilmu dibalik berbagai disiplin ilmu dan perkembangan teknologi modern adalah matematika (Fatmawati \& Ekawati, 2016). Terdapat berbagai kemampuan yang menjadi sasaran dalam pembelajaran matematika di sekolah, salah satunya yaitu berdasarkan Permendiknas No. 22 Tahun 2006. Disebutkan bawa satu dari beberapa tujuan pembelajaran matematika yaitu siswa dapat melakukan pemecahan masalah, termasuk didalamnya pemahaman masalah, perancangan model, peyelesaian, danpenafsiran solusi.

Pemecahan masalah merupakan proses pencapaian tujuan yang terdiri dari proses pengorganisasian konsep dan keterampilan menjadi suatu pola baru (Riffyanti \& Setiawan, 2017). Kemampuan pemecahan masalah matematis memiliki beberapa indikator, diantaranya menurut Sumarmo (Iswara, 2019) yaitu identifikasi kecukupan data, pembuatan model matematika dari permasalahan, pemilihan dan penerapan strategi untuk penyelesaian berbagai masalah intern atau atau ekstern matematika, interpretasi hasil berdasar permasalahan asal, pemeriksaan kebenaran jawaban, dan penerapan matematika bermakna.

NCSM (National Council of Supervisors of Mathematics) menyatakan bahwa belajar penyelesaian masalah menjadi point utama mengapa anak harus belajar matematika (Mulyati, 2016). Dalam pengertian ini, belajar memecahkan masalah dipandang sebagai tujuan belajar matematika. Sejalan dengan itu, Permendiknas No. 22 Tahun 2006 juga menekankan agar kegiatan memecahkan masalah menjadi fokus prioritas dalam belajar matematika di sekolah. Hal tersebut dapat dimengerti karena dalam memecahkan masalah, diperlukan berbagai disiplin konsep terkait yang saing berhubungan. Pentingnya kemampuan siswa dalam memecahkan masalah dipertegas oleh Sumarmo bahwa tujuan pengajaran matematika dan jantungnya matematika adalah pemecahan masalah (Soekisno, 2002).

Permasalahan dalam kehidupan keseharian idealnya menjadi awal pembelajaran matematika. Hal ini disebabkan masalah dalam kehidupan sehari-hari merupakan dasar awal terbentuknya pengetahuan siswa. Surya menyatakan bahwa pembentukan pemahaman matematis siswa akan memberikan keuntungan bagi siswa jika melibatkan pemecahan masalah yang tejadi dalam kehidupan sehari-hari (Nasution \& Manullang, 2017).

Namun kenyataan di lapangan menunjukan bahwa tidak sedikit siswa yang merasakan sulitnya belajar matematika. Hal ini terutama terjadi dalam penyelesaian soal berjenis pemecahan masalah matematis. Keadaan tersebut relevan dengan pendapat Surya tahun 2013 (Nasution \& Manullang, 2017) bahwa kesulitan siswa diperoleh terletak pada saat proses pemahaman, melukis diagram, interpretasi grafik, memahami konsep matematika ranah formal, dan menyelesaikan masalah.

Rendahnya kemampuan pemecahan masalah terbukti dari hasil PISA dimana pemecahan masalah menjadi satu diantara beberapa komponen yang dinilai (Afriansyah, 2016). Indonesia menempati posisi hampir terbawah dalam daftar negara dari segi kualitas pendidikan menurut OECD (2015), tepatnya pada posisi 45 dari 50 negara. Selain itu, masih rendahnya kemampuan pemecahan masalah yang masih rendah juga diketahui dari hasil penelitian Artilita (2015) pada siswa kelas VIII salah satu SMP di Lembang tahun 
pelajaran 2014-2015. Hasil menunjukan bahwa dari 28 siswa, hanya 6 siswa yang menjawab pertanyaan dengan benar. Dengan demikian, diperlukan pengembangan kemampuan pemecahan masalah dengan tujuan siswa memiliki kemampuan pemecahan masalah yang optimal (Rinaldi \& Afriansyah, 2019). Akibatnya, pengembangan kemampuan pemecahan masalah perlu mendapatkan perhatian.

Berbagai penelitian sebelumnya yang memiliki perhatian terhadap kemampuan pemecahan masalah dikaitkan dengan: Pembelajaran Inkuiri (Wardani, 2012); Missouri Mathematics Project (Latifah \& Madio, 2014); Pembelajaran Pelangi Matematika (Rahayu \& Afriansyah, 2015); Pembelajaran Berbasis Masalah (Sumartini, 2016); Creative Problem Solving dan Resource Based Learning (Sopian \& Afriansyah, 2017); Pembelajaran Matematika Berbasis Guided Inquiry (Kurniawati \& Rizkianto, 2018); dan Means End Analysis (Asih \& Ramdhani, 2019).

Kemampuan pemecahan masalah dapat ditingkatkan melalui proses belajar di sekolah. Menurut Trianto (2007), prinsip dari pembelajaran adalah guru memfasilitasi siswa untuk membangun pengetahuannya sendiri. Dalam memfasilitasi siswa, bagian yang memberikan pengaruh besar yaitu model pembelajaran. Hal tersebut karena model pembelajaran dapat membantu guru melakukan pembelajaran dengan baik sehingga akan mempengaruhi hasil pembelajaran.

Para ahli telah mengembangkan beragam model pembelajaran, diantaranya berjenis model pembelajaran kooperatif dengan dasar konstruktivisme. Konstruktivisme merupakan model yang mengharapkan siswa membangun pengetahuannya sendiri. Slavin (2009) menyatakan bahwa dalam pembelajaran kooperatif, akan terjadi diskusi antar siswa, tukar argumen, dan kerja sama dalam kelompok. Siswa akan saling membantu sampai pada proses penyelesaian suatu permasalahan tertentu (Supriatna \& Afriansyah, 2018). Kondisi ini tentu akan membantu siswa dalam melakukan proses pemecahan masalah dengan baik.

Beberapa model pembelajaran yang termasuk kedalam tipe kooperatif diantaranya adalah Think Pair Share. Pengembang pertama model Pembelajaran Kooperatif tipe Think Pair Share adalah Frang Lyman dan temantemanya di Maryland University pada tahun 1997. Beberapa penelitian relevan menerapkan model pembelajaran ini dikaitkan dengan: hasil belajar (Sari \& Madio, 2013), kemampuan penalaran (Octaviyanus \& Ekayanti, 2019), dan lain-lain.

Pembelajaran Think Pair Share menekankan pada tiga tahapan yaitu Think atau berpikir, Pair atau berpasangan, dan Share atau berbagi. Pembelajaran kooperatif tipe Think Pair Share memiliki prosedur tak tampak yang akan memfasilitasi siswa dengan waktu lebih banyak untuk proses berfikir dan menjawab serta saling membantu dalam menghadapi suatu masalah (Syahrul, 2011). Menurut Huda (2012) terdapat tahap-tahap pada pembelajaran Think Pair Share yang mengarahkan siswa untuk memecahkan masalah, yaitu think, pair, dan share. Siswa diberikan kesempatan terlebih dahulu untuk menyelesaikan masalah secara individu. Setelah itu, siswa kemudian membawa hasil pemikirannya untuk didiskusikan pada diskusi kelompok (pasangan). Akibatnya, akan memunculkan berbagai strategi penyelesaian, 
sehingga siswa dapat memilih dan menerapkan strategi dalam pemecahan masalah. Kemampuan pemecahan masalah siswa akan menjadi lebih berkembang baik secara individu maupun berkelompok. Menurut Fogarty \& Robin (Daryanto, 2014), kemampuan siswa dalam mengemukakan pendapat akan terlati dengan penerapan pembelajaran kooperatif tipe Think Pair Share. Pembelajaran ini juga mudah dilaksanakan dalam kelas yang besar.

Tahap-tahap pembelajaran Think Pair Share menurut Majid (2013) yaitu tahap berpikir atau think, tahap berpasangan atau pair, dan tahap berbagi atau share. Pada tahap think, guru akan menyajikan permasalahan pada siswa, selanjutnya siswa diberi kesempatan untuk mencoba memikirkan solusi permasalahan secara perorangan. Pada tahap pair, siswa dipasangkan heterogen untuk saling berdiskusi, membantu dan bertukar ide dalam menyelesaikan permasalahan. Selanjutnya pada tahap share, setiap kelompok ditugaskan untuk berbagi hasil diskusi yang sudah diperoleh kepada kelompok yang lebih besar melalui presentasi di depan kelas. Presentasi dilakukan sampai seperempat kelompok telah mendapat kesempatan untuk melakukan presentasi.

Berdasarkan uraian masalah sebelumnya, maka peneliti tertarik melaksanakan penelitian mengenai pemecahan masalah dengan rumusan pertanyaan: Apakah kemampuan pemecahan masalah matematis siswa meningkat melalui model pembelajaran kooperatif tipe Think Pair Share? Tujuannya yaitu mengetahui peningkatan dan seberapa besar peningkatan kemampuan pemecahan masalah matematis siswa dengan pembelajaran Think Pair Share.

\section{Metode}

Penelitian kuantitatif ini dilakukan dengan metode kuasi eksperimean, dengan populasi yaitu siswa salah satu SMP swasta di Kabupaten Garut kelas VIII tahun pelajaran 2019-2020 semester ganjil. Adapun sampelnya yaitu kelas VIII A. kelas tersebut sekaligus menjadi kelas eksperimen pada penelitian ini.

One Group Pretest-Posttest Design (Tiro dan Ahmar, 2014) digunakan sebagai desaian dalam penelitian ini. Desainnya yaitu:

$$
\begin{array}{lll}
\mathrm{P}_{1} & \mathrm{X} & \mathrm{P}_{2}
\end{array}
$$

Keterangan:

$\mathrm{P}_{1}=$ Instrumen tes awal (pretest)

$\mathrm{X}=$ Perlakuan dengan pembelajaran Think Pair Share

$\mathrm{P}_{2}=$ Instrumen tes akhir (posttest).

Instrumen penelitian berupa tes tulis kemampuan pemecahan masalah berbentuk uraian, yang diujikan tes awal (pretest) dan tes akhir (posttest). Tes awal bertujuan untuk mengetahui kemampuan pemecahan masalah awal siswa sebelum perlakuan. Sedangkan tes akhir dilakukan setelah diberi perlakuan, dan bertujuan untuk mengetahui peningkatan kemampuan pemecahan masalah matematis setelah dapat perlakuan Tes terdiri dari 5 butir soal. Soal tersebut sebelumnya diujicobakan dahulu pada kelas dengan jenjang yang lebih tinggi yang mana kelas tersebut telah mempelajari materi SPLDV sebelumnya. Data hasil uji coba instrumen diolah validitas, reliabilitas, daya pembeda dan tingkat kesukarannya. Hal tersebut dilakukan sebagai menjadi tolak ukur kualitas butir soal yang diberikan.

\section{Hasil dan Pembahasan}

Hasil penelitian ini meliputi hasil pretest dan posttest. Hasil tersebut diolah secara 
statistik deskriptif terlebih dahulu. Adapun hasilnya secara umum adalah sebagai berikut:

Berdasarkan Data pada Tabel 1 diketahui bahwa hasil pretest siswa yang mendapatkan model pembelajaran TPS memperoleh nilai rerata 4,39, sedangkan rerata hasil posttestnya yaitu 10,30 .

\section{A. Analisis Data}

1. Uji Normalitas

Uji Liliefors digunakan untuk menguji kenormalan data. Hasilnya yaitu:

Berdasarkan pada Tabel 2 diperoleh siswa mempunyai nilai $L_{\text {maks }}=0,126<L_{\text {tabel }}=0,154$ merupakan data hasil pretest dan mempunyai nilai $L_{\text {maks }}=0,137<L_{\text {tabel }}=0,154$ merupakan data hasil posttest. Penelitian ini menggunakan $\alpha=5 \%$ denga kriteria normal yaitu jika $L_{\text {maks }}<L_{\text {tabel. }}$ Berdasarkan tabel 2 dapat disimpulkan bahwa hasil pretest dan posttest data berdistribusi normal.

2. Analisis Gain Ternormalisasi

Uji Gain Ternormalisasi (g) dilakukan untuk mengetahui deskripsi secara umum terkait peningkatan hasil belajar (Sundayana, 2014). Peningkatan tersebut dilihat berdasarkan peningkatan hasil pretest dan postest. Adapun data gain ternormalisasi yang dihasilkan yaitu sebagai berikut.

Berdasarkan Tabel 3 diatas dapat diketahui bahwa rerata indeks gain untu kelas TPS sebesar 0,39, maka nilai tersebut tergolong sedang secara statistik, dengan persentase yang menggunakan kategori menurut Hake (1999) yang dimodifikasi oleh Sundayana (2014).

Berdasarkan Tabel 4 dapat disimpulkan bahwa dari 33 siswa, peningkatan kelas TPS dengan kategori sedang sebanyak 55\%, 30\% kategori rendah dan kategori tinggi sebanyak $9 \%$. Kesimpulan secara umum yaitu peningkatan kemampuan pemecahan masalah matematis dengan model Think Pair Share (TPS) berkategori sedang.

\section{B. Deskripsi Hasil Tes}

Pada pertemuan pertama, pembelajaran diawali dengan pemberian pretest di kedua kelas. Pretest dikerjakan dalam hari yang sama dengan durasi 2 × 40 menit. Selanjutnya, pembelajaran dilakukan dengan menerapkan model pembelajaran TPS di kelas VIII-A.

Tabel 1.

Data Kemampuan Pemecahan masalah Matematis

\begin{tabular}{lcc|}
\hline \multicolumn{2}{c}{ Kelas Model TPS } \\
\hline Keterangan & Pretest & Posttest \\
\hline Skor Terkecil & 1 & 3 \\
\hline Skor Terbesar & 9 & 17 \\
\hline Rata-rata & 4,39 & 10,30 \\
\hline $\begin{array}{l}\text { Simpangan } \\
\text { Baku }\end{array}$ & 2,25 & 4,10 \\
\hline Jumlah Siswa & 33 & 33 \\
\hline
\end{tabular}

Tabel 2.

Hasil Uji Normalitas Data Pretest dan Posttest Kemampuan Pemecahan Masalah Matematis

\begin{tabular}{cccc|}
\hline Keterangan & Lmaks & Ltabel & Kriteria \\
\hline Pretest & 0,126 & 0,154 & $\begin{array}{c}\text { Berdistribusi } \\
\text { Normal }\end{array}$ \\
\hline Posttest & 0,137 & 0,154 & $\begin{array}{c}\text { Berdistribusi } \\
\text { Normal }\end{array}$ \\
\hline
\end{tabular}

Tabel 3.

Data Gain Ternormalisasi

\begin{tabular}{lllll}
\hline Kelas & $\begin{array}{l}\text { Skor } \\
\text { Terkecil }\end{array}$ & $\begin{array}{l}\text { Skor } \\
\text { Terbesar }\end{array}$ & $\begin{array}{l}\text { Rata- } \\
\text { rata }\end{array}$ & $\begin{array}{l}\text { Standar } \\
\text { Deviasi }\end{array}$ \\
\hline TPS & 0,00 & 0,75 & 0,39 & 0,22
\end{tabular}

Tabel 4.

Data Persentase Interpretasi

Peningkatan Kemampuan Pemecahan Masalah Matematis

\begin{tabular}{|llcc|}
\hline No. & $\begin{array}{l}\text { Interpretasi } \\
\text { Ternormalisasi }\end{array}$ & $\mathbf{f}_{i}$ & Persentase (\%) \\
\hline 1 & Tinggi & 3 & 9 \\
\hline 2 & Sedang & 18 & 55 \\
\hline 3 & Rendah & 10 & 30 \\
\hline 4 & Tetap & 2 & 6 \\
\hline & Jumlah & 33 & 100 \\
\hline
\end{tabular}


Pertemuan tersebut dilakukan sebanyak empat kali pertemuan kemudian di pertemuan akhir diberikan posttest dan pengisian angket.

Pada pertemuan awal dengan menggunakan model pembelajaran TPS, siswa terlebih dahulu dibagi LKS masing-masing siswa, kemudian dibagi menjadi beberapa kelompok yang berjumlah dua orang setiap kelompoknya. Selama awal kegiatan pembelajaran berlangsung, siswa masih tampak kesulitan dalam mengikuti tahapan pembelajaran dan masih banyak kesulitan dalam mengerjakan LKS bersama teman sekelompoknya. Karena model pembelajaran yang diberikan masih terasa asing bagi siswa. Pada umumnya siswa masih belum sepenuhnya memahami dan keliru mengenai tahapan-tahapan selama proses pembelajaran. Guru perlu memberikan petunjuk dan bimbingan yang lebih kepada para siswa dalam mengerjakan LKS. Sama halnya ketika perwakilan siswa dalam kelompoknya diminta untuk mempresentasikan hasil diskusinya kemudian ditanggapi oleh teman-teman kelompok yang lainnya. Namun, pada pertemuan pembelajaran selanjutnya, siswa mulai

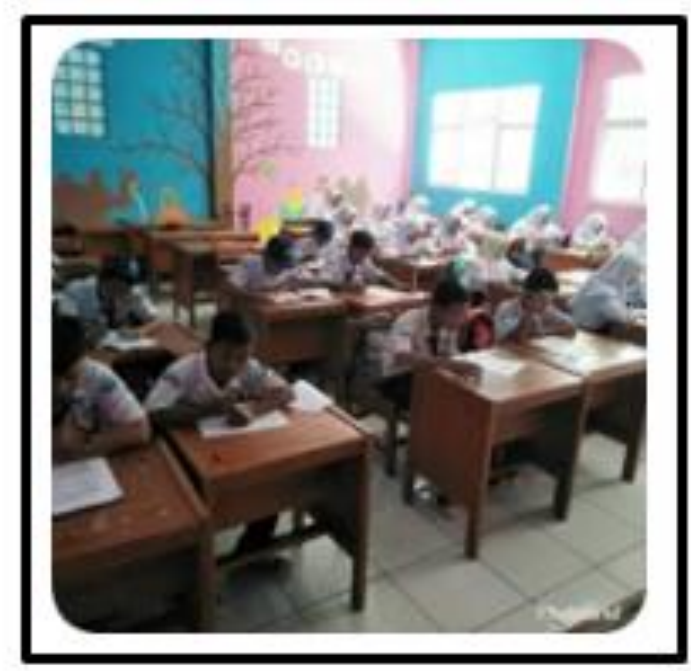

Gambar 1. Tahap Think. terbiasa dan bisa mengikuti tahapan-tahapan proses pembelajaran dengan baik.

Pembelajaran TPS diketahui berpengaruh baik pada proses pembelajaran. Hal tersebut berdasar pada hasil uji gain ternormalisasi yang dilihat dari rerata peningkatan kemampuan pemecahan masalah matematis siswa. Meskipun mendapatkan jadwal pelajaran di siang hari, namun siswa belajar dengan antusias dan tidak membosankan. Setiap kelompok harus mengisi LKS yang menuntun siswa untuk menemukan konsep maupun alternatif penyelesaian dari suatu permasalahan mengenai materi SPLDV.

Berdasarkan pemaparan sebelumya,

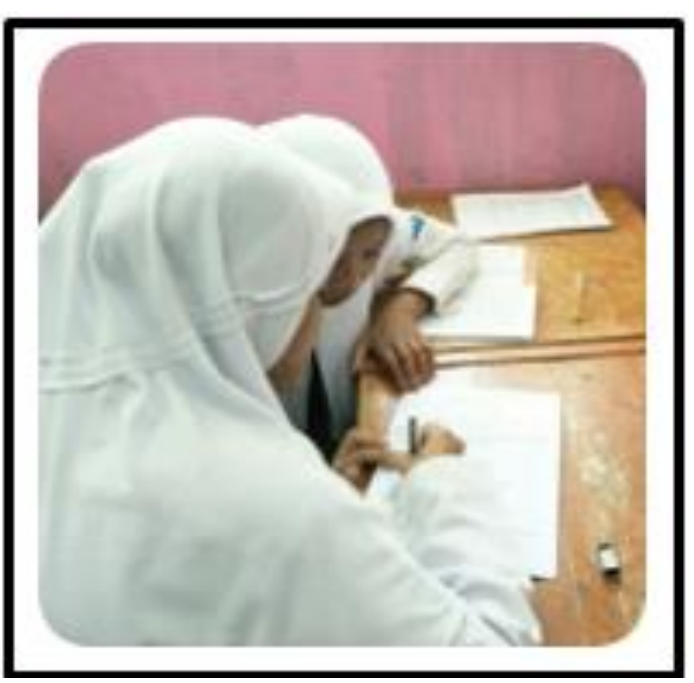

Gambar 2. Tahap Pair.

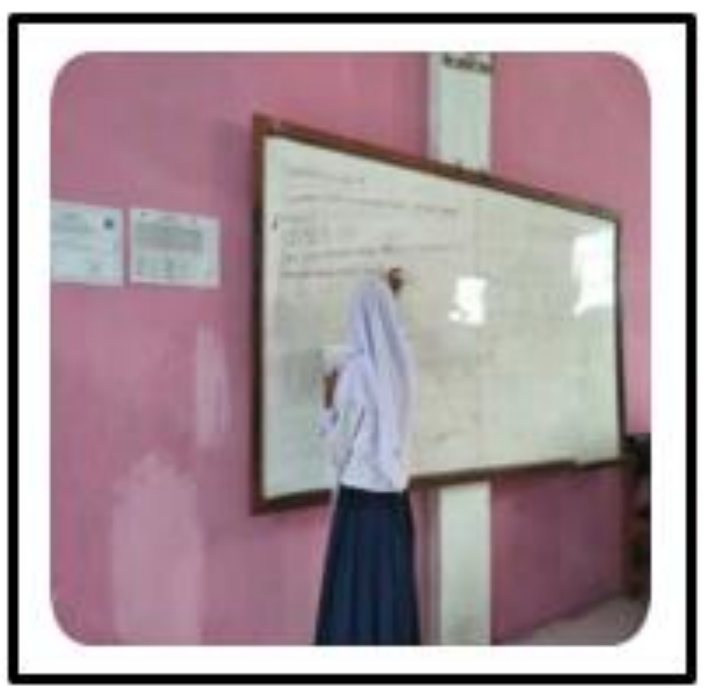

Gambar 3. Tahap Share. 
model pembelajaran TPS meliputi tahapan think, pair dan share. Dalam tahap think, setiap siswa diberi LKS, kemudian siswa diminta untuk membaca, memahami masalah terkait dengan materi SPLDV secara individu yang ditunjukkan oleh Gambar 1 sebagai berikut.

Selanjutnya tahap pair, berkumpul sesuai dengan kelompok yang telah dibuat kemudian siswa berdiskusi serta melakukan percobaan yang telah diperintahkan dalam LKS bersamasama dengan kelompoknya, lalu guru membantu dan membimbing dalam menyamakan hasil pengerjaan LKS yang kemudian dilanjutkan dengan tahap Share yaitu siswa mempresentasikan hasil diskusi kelompoknya dan diamati oleh teman-teman dari kelompok lain. Perhatikan Gambar 2 dan Gambar 3 berikut.

Tahap-tahap tersebut berlangsung selama empat pertemuan, pada setiap pertemuan terlihat beberapa peningkatan baik dari motivasi belajar siswa maupun peningkatan pembelajaran.

Pertemuan pertama di kelas yang mendapatkan model pembelajaran TPS membahas mengenai PLDV dan SPLDV dengan metode Grrafik. Dalam materi ini, siswa diberikan permasalahan dalam kehidupan sehari-hari, kemudian mencatat informasi yang tertera pada permasalahan, dan membuat model matematika, untuk mentukan SPLDV dengan metode grafik siswa mengikuti langkah yang tertera dalam LKS.

Pembelajaran berlangsung sesuai tahapan model pembelajaran TPS. Hanya pada pertemuan pertama tahap diskusi kelompok tidak diikuti oleh semua siswa secara aktif bersama kelompoknya. Siswa masih mengandalkan teman yang pintar untuk menyelesaikan tugas kelompoknya, serta siswa masih terlihat belum tertib dan beberapa masih ngobrol.

Pertemuan kedua membahas mengenai menyelesaikan SPLDV dengan metode substitusi. Sama halnya dengan pertemuan sebelumnya siswa diberikan permasalahan dalam kehidupan sehari-hari, mencatat informasi yang pada permasalahan tersebut, dan membuat model matematika, untuk menentukan SPLDV dengan metode substitusi siswa mengikuti langkah yang tertera dalam LKS. Hampir semua kelompok bisa memahami bagaimana menentukan SPLDV dengan metode substitusi, tetapi siswa terkadang keliru dalam tahap memisalkan salah satu model matematika yang akan disubstitusikan ketika diberikan soal serupa. Namun, pertemuan kedua ini dapat dikatakan lebih baik dibanding pertemuan pertama karena dilihat dari antusias siswa meningkat dalam kegiatan berdiskusi.

Pertemuan ketiga membahas mengenai penyelesaian SPLDV dengan metode eliminasi dan campuran (eliminasi dan substitusi). Sama halnya dengan pertemuan sebelumnya siswa diberikan permasalahan dalam kehidupan sehari-hari, siswa mencatat informasi yang tertera pada permasalahan, kemudian dibuat model matematika, untuk menentukan SPLDV dengan metode eliminasi dan campuran (eliminasi dan substitusi) siswa mengikuti langkah yang tertera dalam LKS. Karena materi yang diberikan cukup rumit mengakibatkan tidak semua kelompok paham mengenai materi yang diberikan. Siswa tampak kebingungan menentukan langkah untuk memahami materi dan menyelesaikan masalah. Mengamati keadaan tersebut, peneliti akhirnya mengambil inisiatif untuk, 
menjelaskan secara langsung dan berulang mengenai soal tersebut untuk menghindari miskonsepsi pada siswa. Pada saat dilakukan penjelasan oleh peneliti, mayoritas siswa memperhatikan penjelasan tersebut dan tampak mulai memahami mengenai materi dan mampu menentukan langkah untuk menyelesaikan masalah.

Pertemuan keempat membahas mengenai menyelesaikan SPLDV khusus. Dalam materi ini siswa melakukan penyelesaian masalah Sistem Persamaan Linear Dua Variabel (SPLDV) dengan metode yang dikuasai siswa, dalam hal ini hasil penyelesaian tersebut memungkinkan memiliki satu selesaian, atau tidak memiliki selesaian atau bahkan memiliki selesaian tak terhingga. Hampir semua kelompok bisa memahami SPLDV khusus, tetapi siswa terkadang keliru dalam menentukan hasil penyelesaian tersebut. Namun, pertemuan keempat ini dapat dikatakan lebih baik dari pertemuan pertama, kedua dan ketiga karena dilihat dari siswa yang mulai fokus dalam membaca serta memahami permasalahan secara individu, dan antusias siswa meningkat dalam kegiatan berdiskusi.

Setelah empat pertemuan selesai dilakukan, siswa diberikan posttest berupa soal-soal yang telah diberikan sebelumnya pada pretest dengan waktu $2 \times 40$ menit atau satu pertemuan untuk mengetahui kemampuan akhir pemecahan masalah matematis siswa maupun respons siswa dari penerapan model pembelajaran yang telah diberikan selama penelitian mengenai materi SPLDV. Hasil analisis tes akhir (posttest) menghasilkan suatu kesimpulan bahwa bahwa terdapat perbedaan kemampuan pemecahan masalah matematis siswa antara awal dan akhir pembelajaran.
Berdasarkan Uji Gain Ternormalisasi dengan rumus yang dikembangkan oleh Hake (1999) dapat dilihat bahwa penerapan pembelajaran Think Pair Share (TPS), secara umum dapat meningkatkan kemampuan pemecahan masalah matematis siswa. Rerata yang didapat adalah 0,39, dengan kategori sedang. Namun terdapat pula siswa yang dengan kategori peningkatan Tinggi.

Setelah pembelajaran dengan Think Pair Share (TPS), peneliti menemukan kelebihan dan kekurangan model pembelajaran tersebut. Kelebihannya yaitu:

1. Kesempatan berpikir secara individu terbuka lebar. Siswa juga berkesempatan bertanya banyak hal yang belum dipahami mengenai materi yang diajarkan.

2. Siswa dapat terlatih memahami konsep dengan baik karena harus bekerja sama dengan temannya untuk mendapatkan kesepakatan (penyelesaian), serta melatih siswa untuk menghargai pendapat temannya.

3. Keaktifan dan keberanian siswa terlatih melalui kegiatan menyampaikan serta menanggapi pendapat.

4. Guru berkesempatan memantau dan membimbing siswa secara leluasa dalam proses pembelajaran.

Adapun beberapa kekurangan penggunaan model pembelajaran TPS, yang peneliti temukan diantaranya:

1. Sulitnya membuat semua siswa dapat terlibat aktif

2. Kesulitan menengahi siswa yang mengalami perselisihan dalam diskusi kelompok.

3. Kondisi kurang kondusif dengan banyaknya kelompok yang melaporkan kesulitan. 
4. Fokus beberapa siswa tidak terarah selama presentasi berlangsung.

5. Beberapa siswa masih kesulitan dalam menyampaikan dan menanggapi pendapat.

Kelebihan model pembelajaran TPS yang dialami peneliti sesuai dengan hasil penelitian Harahap (2018) bahwa penerapan model pembelajaran TPS membuat siswa berkesempatan untuk berpikir individu, sehingga membuat siswa lebih memahami dan aktif berdiskusi bersama anggota kelompoknya untuk menemukan konsep dan memecahkan masalah. Begitupula dengan kelemahan model pembelajaran TPS menurut Lestari (2016) bahwa penerapan model pembelajaran TPS tidak membuat keaktifan pada semua siswa, sehingga tidak semua siswa memahami pelajaran dengan menggunakan model ini.

\section{Penutup}

Model pembelajaran kooperatf tipe think pair share dapat meningkatkan kemampuan pemecahan masalah matematis dengan kualitas peningkatan berada pada interpretasi sedang.

Adapun saran dalam penelitian ini yaitu hendaknya dilakukan beberapa revisi terhadap perlakuan model yang diberikan seperti perincian kegiatan pembelajaran lebih lanjut, perbaikan lembar kerja siswa, dan pembuatan nstrumen yang lebih baik untuk keperluan pembelajaran.

\section{Daftar PUstaka}

Afriansyah, E. A. (2016). The Use of Realistic Approach to Enhance Students' Mathematical Problem Solving Skills.
International Conference on Elementary and Teacher Education ICETE.

Artilita. (2015). Analisis Kemampuan Pemecahan Masalah Matematis siswa SMP Negeri di Lembang. Jurnal Riset pendidikan Matematika, 4(2), 166-175.

Asih, N., \& Ramdhani, S. (2019). Peningkatan Kemampuan Pemecahan Masalah Matematis dan Kemandirian Belajar Siswa Menggunakan Model Pembelajaran Means End Analysis. Mosharafa: Jurnal Pendidikan Matematika, 8(3), 435-446. DOI: https://doi.org/10.31980/mosharafa. v8i3.534

Daryanto. (2014). Pendekatan Pembelajaran Saintifik Kurikulum 2013. Yogyakarta: Gava Media.

Fatmawati, D., \& Ekawati, R. (2016). Pengembangan Soal Matematika Pisa Like Pada Konten Change and Relationship untuk Siswa Sekolah Menengah Pertama. MATHEdunesa: Jurnal IImiah Pendidikan Matematika, 2(5), 29-38.

Hake, R, R. (1999). Analyzing Change/Gain Scores. AREA-D American Education Research Association's Division. D, Measurement and Research Methodology.

Harahap, U. S. (2018). Perbedaan Hasil Belajar Matematika yang diajar dengan Menggunakan Model Pembelajaran Kooperatif Tipe Think Pair Share (TPS) dan Model Pembelajaran Kooperatif Tipe Student Team Achievement Division (STAD) Pada Materi Garis dan Sudut di MTS Al-Jam"iyatul Washliyah. Universitas Islam Negri Sumatera Utara: Diterbitkan. Huda. (2012). Cooperative Learning, Metode, Teknik, Struktural dan Model Penerapan. Yogyakarta: Pustaka Pelajar. 
Iswara, E. (2019). Perbedaan Kemampuan Pemecahan Masalah Matematis dan Self-Confidence Antara Siswa yang Belajar dengan Model Problem Posing dan Direct Intruction. STKIP Garut: Tidak diterbitkan.

Kurniawati, V., \& Rizkianto, I. (2018). Pengembangan Perangkat Pembelajaran Matematika Berbasis Guided Inquiry dan Learning Trajectory Berorientasi pada Kemampuan Pemecahan Masalah. Mosharafa: Jurnal Pendidikan Matematika, $\quad$ 7(3), 369-380. DOI: https://doi.org/10.31980/mosharaf a.v7i3.38

Latifah, D., \& Madio, S. S. (2014). Meningkatkan Kemampuan Pemecahan Masalah Matematis Siswa melalui Model Pembelajaran Missouri Mathematics Project (MMP). Mosharafa: Jurnal Pendidikan Matematika, 3(3), 159-168.

Lestari, M. D. P. (2016). Perbedaan Hasil Belajar Matematika Ditinjau dari Model Pembelajaran Kooperatif Tipe Think Talk Write (TTW) Dan Think Pair Share (TPS) Pada Siswa Kelas VII SMP Negri 7 Yogyakarta. Skripsi pada jurusan Pendidikan Matematika Universitas PGRI Yogyakarta. Diterbitkan.

Majid, A. (2013). Strategi Pembelajaran. Bandung: PT Remaja Rosdakarya.

Mulyati, T. (2016). Kemampuan Pemecahan Masalah Matematis Siswa Sekolah Dasar. Jurnal Pendidikan, 1(7), 1-5.

Nasution, Z. M., \& Manullang, M. (2017). Perbedaan Kemampuan Pemecahan Masalah Matematik Dan Motivasi Belajar Siswa Yang Diberi Pendekatan Pembelajaran Berbasis Masalah Dengan Pendidikan Matematika Realistik Di Smp
Negeri 3 Tebing Tinggi. Jurnal Paradikma 1(10), 1-68.

Octaviyunas, A., \& Ekayanti, A. (2019). Pengaruh Model Pembelajaran Giving Question Getting Answer dan Think Pair Share terhadap Kemampuan Penalaran Matematika Siswa Kelas VII. Mosharafa: Jurnal Pendidikan Matematika, 8(2), 341352.

OECD. (2015). Programme For International Student Assessment (PISA). Diakses dari http://www.oecd.org/pisa/PISA-2015Indonesia.pdf pada tanggal 17 juni 2019. Rahayu, D. V., \& Afriansyah, E. A. (2015). Meningkatkan kemampuan pemecahan masalah matematik siswa melalui model pembelajaran pelangi matematika. Mosharafa: Jurnal Pendidikan Matematika, 4(1), 29-37.

Rifa'i \& Lestari. (2016). Efektivitas Model Pembelajaran Think Pair Share (Tps) Dan Spontaneous Group Discussion (Sgd) Dengan Pendekatan Saintifik Ditinjau Dari Kemampuan Pemecahan Masalah Dan Kepercayaan Diri Siswa Kelas X Mia Di MAN 1 Yogyakarta. Universitas Negri Yogyakarta: Tidak diterbitkan.

Riffyanti, L., \& Setiawan, R. (2017). Analisis Strategi Langkah Mundur dan Bernalar Logis dalam Menentukan Bilangan dan Nilainya. Aksioma: Jurnal Program Studi Pendidikan Matematika, 6(1), 115-127.

Rinaldi, E., \& Afriansyah, E. A. (2019). Perbandingan Kemampuan Pemecahan Masalah Matematis Siswa antara Problem Centered Learning dan Problem Based Learning. NUMERICAL: Jurnal Matematika dan Pendidikan Matematika, 9-18.

Sari, S. P., \& Madio, S. S. (2013). Pengaruh Penerapan Model Pembelajaran Kooperatipe Tipe Think Pair Share (TPS) 
Terhadap Hasil Belajar Matematika Siswa SMP. Mosharafa: Jurnal Pendidikan Matematika, 2(1), 37-54.

Soekisno, B. A. (2002). Kemampuan pemecahan masalah matematika siswa dengan strategi Heustrik. Bandung: Tesis pada jurusan Pendidikan Mtematika Universitas Pendidikan Indonesia. Tidak diterbitkan.

Sopian, Y. A., \& Afriansyah, E. A. (2017). Kemampuan Proses Pemecahan Masalah Matematis Siswa Melalui Model Pembelajaran Creative Problem Solving Dan Resource Based Learning (Studi Eksperimen Pada Siswa Kelas X SMK Krija Bhakti Utama Limbangan). Jurnal Elemen, 3(1), 97-107.

Slavin, R. E. (2009). Cooperative Learning

(Teori, Riset, Praktik). Bandung: Nusa Media.

Supriatna, R., \& Afriansyah, E. A. (2018). Kemampuan Pemahaman Matematis Peserta Didik melalui Cooperative Learning Tipe Pair Checks VS Problem Based Learning. JPMI (Jurnal Pendidikan Matematika Indonesia), 3(1), 1-6.

Sumartini, T. S. (2016). Peningkatan Kemampuan Pemecahan Masalah Matematis Siswa melalui Pembelajaran Berbasis Masalah. Mosharafa: Jurnal Pendidikan Matematika, 5(2), 148-158.

Sundayana, R. (2014). Statistika Penelitian Pendidikan. Bandung: Alfabeta.

Syahrul. (2011). Perbandingan Keefektifan Pembelajaran Cooperative Learning Type STAD (Student Team Achievement Division) Dengan Type TPS (Think-PairShare) Ditinjau Dari Ketercapaian Kompetensi Dasar, Sikap, dan Metode Matematika Siswa SMP. Tesis pada
jurusan
Pendidikan
Matematika
Universitas Negeri Yogyakarta. Tidak diterbitkan.

Tiro, M. A. \& Ahmar, A. S. (2014). Penelitian Eksperimen: Merancang, Melaksanakan, dan Melaporkan. Makassar: Andira Publisher.

Trianto. (2007). Model-Model Pembelajaran Inovatif Berorientasi Konstruktivistik. Jakarta: Prestasi Pustaka.

Wardani, S. (2012). Pembelajaran Inkuiri Model Silver untuk Mengembangkan Kemampuan Pemecahan Masalah dan Disposisi Matematik Siswa Sekolah Menengah Atas. Mosharafa: Jurnal Pendidikan Matematika, 1(1), 9-16.

\section{Riwayat Hidup Penulis}

\section{Syintia Siti Latifah, S.Pd.}

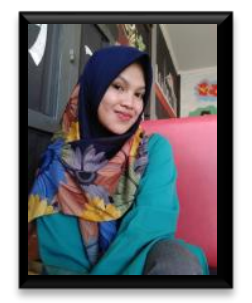

Lahir di Garut, 31 Desember 1996. Studi S1 Pendidikan Matematika Institus Pendidikan Indonesia, Garut, lulus tahun 2019.

\section{Irena Puji Luritawaty, M. Pd.}

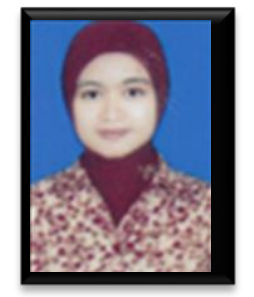

Lahir di Tangerang, 30 April 1988. Staf pengajar di prodi pendidikan matematika di Institut Pendidikan Indonesia Garut. Studi S1 Pendidikan Matematika Sekolah Tinggi Keguruan dan Ilmu Pendidikan Garut, lulus tahun 2010; S2 Pendidikan Matematika Universitas Pendidikan Indonesia, lulus tahun 2014. 
Thispage is intentionally left blank 